\title{
Effect of fungicidal protection on disease agents and improvement of biometric and yield parameters in maize
}

\section{Wpływ ochrony fungicydowej na ograniczenie sprawców chorób oraz poprawę parametrów biometrycznych i plonowania kukurydzy}

\author{
Barbara Krzyzińska*, Mariola Głazek
}

\section{Summary}

The studies conducted in 2008-2012 were designed to determine the optimal period of fungicide application and assess its effect on reducing the occurrence of fungal diseases and maize biometrics, including quantity and quality of grain yield. Strobilurin, benzimidazole and triazole fungicides were used in the study. The trials were conducted on maize cultivars of different maturity, i.e. length of active growth, and different susceptibility to diseases. The results indicate that maize leaves were best protected against fungal diseases by mixes of triazoles and strobilurins. The most effective timing for spraying maize crop with the mix of fun gicides was at $\mathrm{BBCH} 39-51$.

Key words: fungicides; maize; Exserohilum turcicum; pyraclostrobin; epoxiconazole

\section{Streszczenie}

W latach 2008-2012 prowadzono badania w celu wyznaczenia optymalnego terminu ochrony fungicydowej i określenia jej wpływu na ograniczenie występowania sprawców chorób oraz na parametry biometryczne, plonowanie kukurydzy oraz jakość uzyskanego ziarna. W doświadczeniach zastosowano fungicydy z grupy: strobiluryn, benzymidazoli i triazoli. Przeprowadzono je na odmianach kukurydzy różniących się znacznie wczesnością, czyli długością wegetacji, a co za tym idzie wrażliwością na choroby. Uzyskane wyniki wskazują, że najlepszą efektywność działania fungicydów w ochronie liści kukurydzy przed sprawcami chorób przyniosło zastosowanie środków opartych na mieszaninie triazoli i strobiluryny. Najbardziej efektywnym terminem zwalczania chorób w uprawie kukurydzy było zastosowanie zabiegu opryskiwania w fazie rozwojowej rośliny uprawnej BBCH 39-51.

Słowa kluczowe: fungicydy; kukurydza; Exserohilum turcicum; piraklostrobina; epoksykonazol

Instytut Ochrony Roślin - Państwowy Instytut Badawczy

Zakład Badania Skuteczności Środków Ochrony Roślin

Oddział Sośnicowice

Gliwicka 29, 44-153 Sośnicowice

*corresponding author: b.krzyzinska@ior.gliwice.pl 


\section{Wstęp / Introduction}

Jednym z istotnych czynników wpływających na plonowanie kukurydzy są choroby, których sprawcy byli do niedawna niedocenianą grupą agrofagów. Według badań choroby mogą się przyczynić do $20-30 \%$ strat w plonach kukurydzy (Munkvold i wsp. 2001; Tekiela 2001). W Polsce południowej, jak i na południu Europy (Blandino i wsp. 2012), dominującą chorobą kukurydzy jest żółta plamistość liści [Exserohilum turcicum (Pass.) K.J. Leonard \& Suggs]. W późniejszych fazach rozwojowych często także występuje drobna plamistość liści kukurydzy (Kabatiella zeae Nortia \& Hiratsuka) oraz rdza kukurydzy (Puccinia sorghi Schw.). Tekiela (2005) uważa, że najczęściej zasiedlającymi uprawę kukurydzy w Polsce są grzyby K. zeae i E. turcicum. Natomiast kolby kukurydzy często porażane są przez grzyby rodzaju Fusarium, których występowanie wpływa na pogorszenie jakości ziarna oraz zwiększenie zawartości mikotoksyn w ziarnie (Nelson i wsp. 1993). W ciągu ostatnich lat, w wielu krajach, wzrosło znaczenie stosowania fungicydów w ochronie kukurydzy (Munkvold i wsp. 2008; Da Cunha i wsp. 2010). Odnotowano również rosnące zainteresowanie stosowaniem dolistnych fungicydów w uprawie kukurydzy, ponieważ oprócz zapewnienia ochrony przed chorobami, indukują także korzyści fizjologiczne dla roślin (Wu i von Tiedemann 2001).

Celem badań była ocena efektywności działania fungicydów w ograniczeniu występowania sprawców chorób kukurydzy oraz wyznaczenie optymalnego terminu ich aplikacji. Badano także wpływ zastosowanej ochrony fungicydowej na poprawę parametrów fizjologicznych i biometrycznych kukurydzy. Wyznacznikiem efektywności działania środków grzybobójczych było uzyskanie wysokich plonów dobrej jakości.

\section{Materiały i metody / Materials and methods}

W latach 2008-2010 prowadzono badania w Instytucie Ochrony Roślin - Państwowym Instytucie Badawczym, Oddział Sośnicowice nad efektywnością działania ochrony fungicydowej w uprawie kukurydzy. Doświadczenia były zlokalizowane w pobliżu miejscowości Sośnicowice, województwo śląskie (współrzędne geograficzne: szer. 50,27058; dług. 18,54156). Jednoczynnikowe doświadczenia zakładano na poletkach o powierzchni $25 \mathrm{~m}^{2} \mathrm{w}$ układzie bloków losowanych, w 4 powtórzeniach, na różnych odmianach kukurydzy: Amadeo (2008; FAO 240), Nimba (2009; FAO 260), Buran (2009; FAO 240), Gracja (20092011; FAO 270), Ronaldinio (2010; FAO 260), Eco (2010; FAO 250), System (2012; FAO 240), Havene (2011; FAO 270) i Kajfus (2012; FAO 300). Zabieg opryskiwania wykonano w fazie kwitnienia (BBCH 61-69) fungicydami z grupy: strobiluryn, benzymidazoli i triazoli, zawierającymi substancje czynne charakteryzujące się działaniem systemicznym, takie jak: epoksykonazol, tiofanat metylu i metkonazol oraz translaminarnym - piraklostrobina.

W latach 2011-2012 w celu określenia optymalnego momentu wykonania zabiegu ochrony fungicydowej przeprowadzono doświadczenia, w których zabieg oprys- kiwania kukurydzy wykonano w 6 terminach: termin „A" BBCH 19 (faza 9 liści), termin „B” BBCH 31-32 (faza jednego do dwóch kolanek) oraz $\mathrm{w}$ terminach od „C" do „F” w tygodniowych odstępach (,C” BBCH 34 faza 4. kolanka; „D” BBCH 39 faza 9. kolanka; „E” BBCH 51-59 rozwój wiechy i „F” BBCH 69 koniec kwitnienia). Badania prowadzono $\mathrm{z}$ fungicydem zawierającym epoksykonazol i piraklostrobinę. Poszczególne obiekty doświadczenia przedstawiono w tabelach 1-4 uwzględniając dawkę zastosowanych środków oraz termin aplikacji.

Nasilenie chorób oceniano na podstawie porażenia powierzchni liści kukurydzy w fazie pełnej dojrzałości mlecznej ziarniaków (BBCH 75), w fazie pełnej dojrzałości woskowej (BBCH 85) i w fazie dojrzałości fizjologicznej (BBCH 87). W tych samych terminach określano także zachowaną powierzchnię asymilacyjną liści kukurydzy. Oceniono plon ziarna kukurydzy przeliczony na stałą wilgotność 14\% oraz plon zielonej masy kukurydzy. Po uzyskaniu stabilnej wilgotności ziarniaków porównywano masę tysiąca ziaren.

Wykonano również oceny biometryczne kolb kukurydzy - długość oraz procent wypełnienia kolb ziarniakami.

Obliczenia wykonano przy pomocy programu STATISTICA v. 8.0, stosując analizę wariancji ANOVA. Wyniki poddano analizie statystycznej i porównano za pomocą testu statystycznego Duncana na poziomie istotności $\mathrm{p}=0,05$.

\section{Wyniki i dyskusja / Results and discussion}

Podczas ocen wykonywanych od fazy dojrzałości mlecznej ziarniaków aż do fazy dojrzałości fizjologicznej (BBCH 75-87) stwierdzono, że porażona powierzchnia liści przez sprawców chorób, w obiektach, w których zastosowano ochronę fungicydową była istotnie niższa niż w obiekcie niechronionym (tab. 1, 2). Wysoka efektywność działania badanych środków grzybobójczych, utrzymywała się przez wiele tygodni od zastosowania. Liczni autorzy w swoich badaniach prezentowali wysoką aktywność biologiczną fungicydów wobec grzybów patogenicznych będących sprawcami: drobnej plamistości liści kukurydzy, żółtej plamistości liści kukurydzy oraz rdzy kukurydzy (Bowen i Pedersen 1988; Pataky i Eastburn 1993). Najlepszą efektywność działania w zwalczaniu grzybów: E. turcicum, K. zeae i P. sorghi obserwowano w kombinacjach doświadczalnych, w których zastosowano mieszaninę epoksykonazolu i piraklostrobiny (tab. 1). Taki pozytywny efekt zastosowania mieszaniny strobiluryny i triazolu w zwalczaniu żółtej plamistości liści kukurydzy obserwowali także Blandino i wsp. (2012). Wyniki uzyskane w badaniach własnych wskazują, że skuteczność działania fungicydów była ściśle związana $\mathrm{z}$ terminem ich aplikacji. Średni procent porażonej powierzchni liści był najmniejszy $\mathrm{w}$ obiektach $\mathrm{z}$ zastosowaniem fungicydu w terminie D i E (BBCH 39 i BBCH 51-59) w stosunku do terminów wcześniejszych A (BBCH 19), B (BBCH 31-32) i C (BBCH 34) oraz terminu późniejszego $\mathrm{F}$ (BBCH 69) (tab. 2). W doświadczeniach prowadzonych przez Munkvold i Gorman (2006) największą efektywność zwalczania 
sprawców chorób kukurydzy odnotowano po zastosowaniu środków grzybobójczych w fazie początku kwitnienia, natomiast $\mathrm{w}$ warunkach wysokiego porażenia liści kukurydzy przez grzyb E. turcicum, pod koniec wegetacji obserwowano znaczne zmniejszenie porażenia liści po zastosowaniu fungicydów od fazy 5 kolanka $(\mathrm{BBCH} 35)$ do fazy dojrzałości mlecznej (BBCH 75) (Blandino i wsp. 2012).

Tabela 1. Wpływ ochrony fungicydowej na porażenie liści przez sprawców chorób oraz na parametry biometryczne kolb kukurydzy Table 1. Effect of fungicide protection on infection of maize leaves by fungal diseases and on biometric characteristics of maize cobs

\begin{tabular}{|c|c|c|c|c|c|c|c|c|c|c|}
\hline \multirow[t]{2}{*}{$\begin{array}{l}\text { Kombinacje } \\
\text { doświadczalne } \\
\text { Treatments }\end{array}$} & \multirow{2}{*}{$\begin{array}{l}\text { Termin } \\
\text { aplikacji; } \\
\text { dawka na ha } \\
\text { Time of } \\
\text { application; } \\
\text { dose per ha }\end{array}$} & \multicolumn{3}{|c|}{$\begin{array}{c}\text { Żółta plamistość liści kukurydzy } \\
\text { (Exserohilum turcicum) } \\
\text { porażona powierzchnia liści } \\
\text { infected leaf area } \\
{[\%]}\end{array}$} & \multirow{2}{*}{\begin{tabular}{|} 
Drobna \\
plamistość \\
liści \\
kukurydzy \\
(Kabatiella \\
zeae $)$ \\
porażona \\
powierzchnia \\
liści \\
infected \\
leaf area \\
{$[\%]$} \\
BBCH 87
\end{tabular}} & \multicolumn{3}{|c|}{$\begin{array}{c}\text { Rdza kukurydzy } \\
(\text { Puccinia sorghi }) \\
\text { porażona powierzchnia liści } \\
\text { infected leaf area } \\
{[\%]}\end{array}$} & \multirow{2}{*}{$\begin{array}{l}\begin{array}{c}\text { Długość } \\
\text { kolby } \\
\text { Lenght of } \\
\text { the cobs } \\
{[\mathrm{cm}]}\end{array} \\
\mathrm{BB}\end{array}$} & \multirow{2}{*}{$\begin{array}{l}\text { Wypełnienie } \\
\text { kolb } \\
\text { ziarnem } \\
\text { Full-kernels } \\
\text { cobs } \\
{[\%]} \\
\\
\\
\text { H } 87\end{array}$} \\
\hline & & ВBCH 75 & BBCH 85 & ВBCH 87 & & BBCH 75 & ВBCH 85 & BBCH 87 & & \\
\hline $\begin{array}{l}\text { Kontrola } \\
\text { Untreated }\end{array}$ & - & $4,79 \mathrm{a}$ & $17,08 \mathrm{a}$ & 34,16 a & $30,00 \mathrm{a}$ & $2,48 \mathrm{a}$ & 8,49 a & 13,79 a & $16,42 \mathrm{a}$ & 96,17 a \\
\hline $\begin{array}{l}\text { Epoxiconazole } \\
+ \\
\text { pyraclostrobin }\end{array}$ & $\begin{array}{c}\text { А BBCH } \\
61-69 ; 1,51\end{array}$ & $0,44 \mathrm{~b}$ & $6,95 \mathrm{~b}$ & $18,54 \mathrm{~b}$ & $5,88 \mathrm{~b}$ & $0,39 \mathrm{~b}$ & $2,75 \mathrm{~b}$ & $5,58 \mathrm{~b}$ & $17,21 \mathrm{a}$ & 96,55 a \\
\hline $\begin{array}{l}\text { Thiophanate- } \\
\text { methyl + } \\
\text { epoxiconazole }\end{array}$ & $\begin{array}{c}\text { А BBCH } \\
61-69 ; 0,61\end{array}$ & $1,00 \mathrm{~b}$ & $7,37 \mathrm{~b}$ & $19,33 \mathrm{~b}$ & $10,88 \mathrm{~b}$ & $0,52 \mathrm{~b}$ & $3,37 \mathrm{~b}$ & $6,52 \mathrm{~b}$ & $16,66 \mathrm{a}$ & 96,41 a \\
\hline Metconazole & $\begin{array}{c}\text { A BBCH } \\
61-69 ; 1,21\end{array}$ & $0,98 \mathrm{~b}$ & $7,14 \mathrm{~b}$ & $19,00 \mathrm{~b}$ & $8,35 \mathrm{~b}$ & $0,65 \mathrm{~b}$ & $3,40 \mathrm{~b}$ & $6,25 \mathrm{~b}$ & $16,42 \mathrm{a}$ & 96,36 a \\
\hline
\end{tabular}

Wartości oznaczone tą samą literą nie różnią się istotnie - Values followed by the same letter are not significantly different

Tabela 2. Wpływ terminu zastosowania ochrony fungicydowej na porażenie liści przez sprawców chorób oraz na parametry biometryczne kolb kukurydzy

Table 2. Effect of the timing of fungicidal treatment on infection of maize leaves by fungal diseases and on biometric characteristics of maize cobs

\begin{tabular}{|c|c|c|c|c|c|c|c|c|}
\hline \multirow[t]{2}{*}{$\begin{array}{c}\text { Kombinacje doświadczalne } \\
\text { Treatments }\end{array}$} & \multirow[t]{2}{*}{$\begin{array}{l}\text { Termin aplikacji; } \\
\text { dawka na ha } \\
\text { Time of application; } \\
\text { dose per ha }\end{array}$} & \multicolumn{3}{|c|}{$\begin{array}{c}\text { Żółta plamistość liści kukurydzy } \\
\text { (Exserohilum turcicum) } \\
\text { porażona powierzchnia liści } \\
\text { infected leaf area } \\
{[\%]}\end{array}$} & \multicolumn{2}{|c|}{$\begin{array}{c}\text { Drobna plamistość } \\
\text { liści kukurydzy } \\
(\text { Kabatiella zeae }) \\
\text { porażona } \\
\text { powierzchnia liści } \\
\text { infected leaf area } \\
{[\%]}\end{array}$} & $\begin{array}{l}\text { Długość } \\
\text { kolby } \\
\text { Lenght of } \\
\text { the cobs } \\
{[\mathrm{cm}]}\end{array}$ & $\begin{array}{l}\text { Wypełnienie } \\
\text { kolb ziarnem } \\
\text { Full-kernels } \\
\text { cobs } \\
{[\%]}\end{array}$ \\
\hline & & BBCH 75 & BBCH 85 & BBCH 87 & BBCH 85 & BBCH 87 & $\mathrm{BB}$ & CH 87 \\
\hline Kontrola - Untreated & - & $17,50 \mathrm{a}$ & $21,75 \mathrm{a}$ & $24,75 \mathrm{a}$ & $5,00 \mathrm{a}$ & $5,50 \mathrm{a}$ & $15,50 \mathrm{~d}$ & $93,61 \mathrm{~b}$ \\
\hline Epoxiconazole + pyraclostrobin & A BBCH 19; 1,51 & $11,25 \mathrm{~b}$ & $16,75 \mathrm{~b}$ & $18,25 \mathrm{~b}$ & $1,50 \mathrm{~b}$ & $1,75 \mathrm{~b}$ & $15,92 \mathrm{~cd}$ & $95,19 \mathrm{ab}$ \\
\hline Epoxiconazole + pyraclostrobin & В ВВСН $31-32 ; 1,51$ & $10,75 \mathrm{~b}$ & $14,75 \mathrm{~b}$ & $16,50 \mathrm{~b}$ & $1,25 \mathrm{~b}$ & $2,25 \mathrm{~b}$ & $16,10 \mathrm{~cd}$ & $95,90 \mathrm{a}$ \\
\hline Epoxiconazole + pyraclostrobin & С ВВCH $34 ; 1,51$ & $10,75 \mathrm{~b}$ & $12,75 \mathrm{~b}$ & $14,75 \mathrm{~b}$ & $0,75 \mathrm{bc}$ & $1,50 \mathrm{bc}$ & $16,62 \mathrm{abc}$ & 95,99 a \\
\hline Epoxiconazole + pyraclostrobin & D $\quad$ BBCH $39 ; 1,51$ & $7,25 \mathrm{c}$ & $10,50 \mathrm{c}$ & $12,25 \mathrm{c}$ & $0,00 \mathrm{c}$ & $1,00 \mathrm{c}$ & $16,97 \mathrm{ab}$ & $97,09 \mathrm{a}$ \\
\hline Epoxiconazole + pyraclostrobin & Е ВBCH 51-59; 1,5 1 & $6,75 \mathrm{c}$ & $10,75 \mathrm{c}$ & $11,00 \mathrm{c}$ & $0,00 \mathrm{c}$ & $0,50 \mathrm{c}$ & $17,13 \mathrm{a}$ & $96,80 \mathrm{a}$ \\
\hline Epoxiconazole + pyraclostrobin & F $\mathrm{BBCH} 69 ; 1,51$ & $10,25 \mathrm{~b}$ & $12,00 \mathrm{c}$ & $14,20 \mathrm{~b}$ & $0,50 \mathrm{bc}$ & $1,00 \mathrm{c}$ & $16,17 \mathrm{~cd}$ & $95,14 \mathrm{ab}$ \\
\hline
\end{tabular}

Wartości oznaczone tą samą literą nie różnią się istotnie - Values followed by the same letter are not significantly different 年 i Ames (2010) wskazują, że środki grzybobójcze opóźniają starzenie się roślin, a tym samym przedłużają ich wegetację. W badaniach własnych także obserwowano, że 
Tabela 3. Wpływ ochrony fungicydowej na zachowaną powierzchnię asymilacyjną liści kukurydzy, plon ziarna, zielonej masy i masy tysiąca ziaren kukurydzy

Table 3. Effect of fungicidal treatments on green leaf area, grain yield, green weight and thousand grain weight of maize

\begin{tabular}{|c|c|c|c|c|c|c|c|c|c|c|}
\hline \multirow[b]{2}{*}{$\begin{array}{l}\text { Kombinacje } \\
\text { doświadczalne } \\
\text { Treatments }\end{array}$} & \multirow[b]{2}{*}{$\begin{array}{c}\text { Termin } \\
\text { aplikacji; } \\
\text { dawka na ha } \\
\text { Time of } \\
\text { application; } \\
\text { dose per ha }\end{array}$} & \multicolumn{3}{|c|}{$\begin{array}{c}\text { GLA } \\
\text { Powierzchnia - area } \\
{[\%]}\end{array}$} & \multicolumn{2}{|c|}{$\begin{array}{l}\text { Plon ziarna } \\
\text { Grain yield }\end{array}$} & \multicolumn{2}{|c|}{$\begin{array}{l}\text { Plon zielonej masy } \\
\text { Green weight yield }\end{array}$} & \multicolumn{2}{|c|}{$\begin{array}{l}\text { Masa tysiąca ziaren } \\
\text { Thousand grain weight }\end{array}$} \\
\hline & & ВBCH 75 & ВBCH 85 & ВBCH 87 & {$[\mathrm{t} / \mathrm{ha}]$} & $\begin{array}{c}\text { wzrost } \\
\text { w stosunku } \\
\text { do kontroli } \\
\text { increase as } \\
\text { compared } \\
\text { to control } \\
{[\%]}\end{array}$ & {$[\mathrm{t} / \mathrm{ha}]$} & $\begin{array}{c}\text { wzrost } \\
\text { w stosunku } \\
\text { do kontroli } \\
\text { increase as } \\
\text { compared } \\
\text { to control } \\
{[\%]}\end{array}$ & {$[\mathrm{g}]$} & $\begin{array}{c}\text { wzrost } \\
\text { w stosunku } \\
\text { do kontroli } \\
\text { increase as } \\
\text { compared } \\
\text { to control } \\
{[\%]}\end{array}$ \\
\hline $\begin{array}{l}\text { Kontrola } \\
\text { Untreated }\end{array}$ & - & $84,78 \mathrm{c}$ & $61,89 \mathrm{~b}$ & $34,19 \mathrm{~b}$ & $15,00 \mathrm{~b}$ & 100 & $44,10 \mathrm{~b}$ & 100 & $313,01 \mathrm{~b}$ & 100 \\
\hline $\begin{array}{l}\text { Epoxiconazole + } \\
\text { pyraclostrobin }\end{array}$ & $\begin{array}{l}\text { A BBCH } \\
61-69 ; 1,51\end{array}$ & 94,09 a & $75,30 \mathrm{a}$ & 61,79 a & $16,82 \mathrm{a}$ & 112 & 56,59 a & 128 & $320,41 \mathrm{a}$ & 102 \\
\hline $\begin{array}{l}\text { Thiophanate- } \\
\text { methyl } \\
+ \\
\text { epoxiconazole }\end{array}$ & $\begin{array}{l}\text { А BBCH } \\
61-69 ; 0,61\end{array}$ & $92,32 \mathrm{~b}$ & 72,09 a & $61,04 \mathrm{a}$ & $16,48 \mathrm{a}$ & 110 & 54,49 a & 123 & $319,95 \mathrm{a}$ & 102 \\
\hline Metconazole & $\begin{array}{l}\text { A BBCH } \\
61-69 ; 1,21\end{array}$ & $91,80 \mathrm{~b}$ & $71,00 \mathrm{a}$ & 60,79 a & $16,22 \mathrm{a}$ & 108 & $55,56 \mathrm{a}$ & 126 & $318,85 \mathrm{a}$ & 102 \\
\hline
\end{tabular}

GLA - zielona powierzchnia liścia - green leaf area

Wartości oznaczone tą samą literą nie różnią się istotnie - Values followed by the same letter are not significantly different

Tabela 4. Wpływ zabiegów opryskiwania na zachowaną powierzchnię asymilacyjną liści kukurydzy, plon ziarna, zielonej masy i masy tysiaca ziaren kukurydzy

Table 4. Effect of fungicidal treatments on green leaf area, grain yield, green weight and thousand grain weight of maize

\begin{tabular}{|c|c|c|c|c|c|c|c|c|c|c|}
\hline \multirow[b]{2}{*}{$\begin{array}{l}\text { Kombinacje } \\
\text { doświadczalne } \\
\text { Treatments }\end{array}$} & \multirow[b]{2}{*}{$\begin{array}{l}\text { Termin aplikacji; } \\
\text { dawka na ha } \\
\text { Time of application; } \\
\text { dose per ha }\end{array}$} & \multicolumn{3}{|c|}{$\begin{array}{c}\text { GLA } \\
\text { powierzchnia - area } \\
{[\%]}\end{array}$} & \multicolumn{2}{|c|}{$\begin{array}{l}\text { Plon ziarna } \\
\text { Grain yield }\end{array}$} & \multicolumn{2}{|c|}{$\begin{array}{c}\text { Plon } \\
\text { zielonej masy } \\
\text { Green weight yield }\end{array}$} & \multicolumn{2}{|c|}{$\begin{array}{c}\text { Masa } \\
\text { tysiąca ziaren } \\
\text { Thousand grain weight }\end{array}$} \\
\hline & & BBCH 75 & $\mathrm{BBCH} 85$ & BBCH 87 & {$[\mathrm{t} / \mathrm{ha}]$} & \begin{tabular}{|c|} 
wzrost \\
w stosunku \\
do kontroli \\
increase as \\
compared \\
to control \\
{$[\%]$}
\end{tabular} & [t/ha] & \begin{tabular}{|c|} 
wzrost \\
w stosunku \\
do kontroli \\
increase as \\
compared \\
to control \\
{$[\%]$}
\end{tabular} & {$[\mathrm{g}]$} & $\begin{array}{c}\text { wzrost } \\
\text { w stosunku } \\
\text { do kontroli } \\
\text { increase as } \\
\text { compared } \\
\text { to control } \\
{[\%]}\end{array}$ \\
\hline $\begin{array}{l}\text { Kontrola } \\
\text { Untreated }\end{array}$ & - & $78,80 \mathrm{~b}$ & $51,30 \mathrm{c}$ & $40,00 \mathrm{c}$ & $12,41 \mathrm{~d}$ & 100 & $24,59 \mathrm{c}$ & 100 & $381,80 \mathrm{c}$ & 100 \\
\hline $\begin{array}{l}\text { Epoxiconazole } \\
+ \text { pyraclostrobin }\end{array}$ & А ВВСН 19; 1,51 & $87,50 \mathrm{a}$ & $62,50 \mathrm{ab}$ & $51,30 \mathrm{~b}$ & $12,50 \mathrm{~d}$ & 101 & $26,70 \mathrm{bc}$ & 108 & $383,90 \mathrm{bc}$ & 100 \\
\hline $\begin{array}{l}\text { Epoxiconazole } \\
+ \text { pyraclostrobin }\end{array}$ & В ВBCH $31-32 ; 1,51$ & 88,30 a & $60,00 \mathrm{~b}$ & $53,80 \mathrm{ab}$ & $12,90 \mathrm{~cd}$ & 104 & $26,94 \mathrm{bc}$ & 109 & $385,20 \mathrm{bc}$ & 101 \\
\hline $\begin{array}{l}\text { Epoxiconazole } \\
+ \text { pyraclostrobin }\end{array}$ & С $\mathrm{BBCH} 34 ; 1,51$ & $86,30 \mathrm{a}$ & $61,30 \mathrm{~b}$ & $52,50 \mathrm{ab}$ & $13,25 \mathrm{bc}$ & 107 & $27,84 \mathrm{~b}$ & 113 & $386,70 \mathrm{~b}$ & 101 \\
\hline $\begin{array}{l}\text { Epoxiconazole } \\
+ \text { pyraclostrobin }\end{array}$ & D $\mathrm{BBCH} 39 ; 1,51$ & 88,30 a & $68,80 \mathrm{a}$ & 58,80 a & $13,91 \mathrm{a}$ & 112 & 29,43 a & 120 & $392,40 \mathrm{a}$ & 103 \\
\hline $\begin{array}{l}\text { Epoxiconazole } \\
+ \text { pyraclostrobin }\end{array}$ & E $\mathrm{BBCH} 51-59 ; 1,51$ & 88,80 a & $58,80 \mathrm{~b}$ & $53,80 \mathrm{ab}$ & $13,70 \mathrm{ab}$ & 110 & $27,60 \mathrm{~b}$ & 112 & $387,70 \mathrm{~b}$ & 101 \\
\hline $\begin{array}{l}\text { Epoxiconazole } \\
+ \text { pyraclostrobin }\end{array}$ & F ВBCH 69; 1,5 1 & $87,50 \mathrm{a}$ & $57,50 \mathrm{bc}$ & $48,80 \mathrm{~b}$ & $12,93 \mathrm{~cd}$ & 104 & $26,76 \mathrm{bc}$ & 109 & $387,20 \mathrm{~b}$ & 101 \\
\hline
\end{tabular}

GLA - zielona powierzchnia liścia - green leaf area

Wartości oznaczone tą samą literą nie różnią się istotnie - Values followed by the same letter are not significantly different

w fazie dojrzałości fizjologicznej (BBCH 87) zachowana powierzchnia asymilacyjna była dwukrotnie wyższa niż w obiekcie kontrolnym. Ma to duże znaczenie w przypadku odmian uprawianych na kiszonkę, ponieważ może opóźnić zbiory. Stwierdzono także statystycznie istotne zróżnicowanie zachowanej powierzchni asymilacyjnej liści kukurydzy po zastosowaniu fungicydu zawierającego epoksykonazol i pyraklostrobinę (tab. 4). W fazie pełnej 
dojrzałości woskowej ziarniaków i dojrzałości fizjologicznej największą powierzchnię asymilacyjną obserwowano w kombinacjach doświadczalnych, w których aplikację wykonano w terminie „D”. Według badań Below i wsp. (2009) zastosowanie strobiluryny powoduje zmniejszenie wydzielania przez kukurydzę etylenu, hormonu odpowiedzialnego za dojrzewanie i starzenie się roślin. Blandino i wsp. (2012) także obserwowali lepsze efekty fizjologiczne na roślinach kukurydzy opryskiwanych w fazie rozwojowej BBCH 35 w porównaniu do zabiegów wykonanych wcześniej, a także później.

W przypadku oceny dotyczącej wpływu fungicydów na cechy biometryczne kolb kukurydzy obserwowano silne powiązania między terminem aplikacji a uzyskanymi wzrostami długości kolb i procentem ich wypełnienia przez ziarniaki. Stwierdzono istotny wzrost tych parametrów na korzyść środków grzybobójczych, które aplikowano w terminie od fazy BBCH 34 do fazy 51-59 (tab. 1, 2). Lejeune i Barnier (1996) także obserwowali pozytywny efekt zastosowania fungicydów w fazie rozwojowej BBCH 13-15 na cechy biometryczne kolb kukurydzy takich, jak wzrost liczebności ziarniaków kukurydzy w rzędzie oraz wzrost rzędów na kolbach kukurydzy.

Wzrost nasilenia występowania chorób w uprawie kukurydzy w dużym stopniu wpływa na obniżenie plonu ziarna rośliny uprawnej (Munkvold i wsp. 2001). W wyniku badań Nelson i Meinhardt (2011) stwierdzili, że środki grzybobójcze zawierające strobiluryny, nawet w przypadku braku porażenia kukurydzy przez sprawców chorób, wpływają korzystnie na fizjologię roślin i powodują wzrost plonu ziarna. W badaniach własnych statystycznie istotny wzrost plonu ziarna na poziomie $8-12 \%$ wobec kontroli uzyskano we wszystkich kombinacjach opryskiwanych fungicydami. Plon zielonej masy w obiektach z zastosowaniem środków grzybobójczych wzrósł o 23-28\% w stosunku do kombinacji niechronionej (tab. 3). Duże znaczenie dla wzrostu plonu ziarna i zielonej masy kukurydzy miał też termin zastosowania ochrony fungicydowej. Pozytywny efekt, czyli uzyskanie zwyżki plonu ziarna (7-12\% więcej niż w kontroli) i zielonej masy kukurydzy (12-20\%), przyniosły jedynie aplikacje wykonane między fazą rozwojową kukurydzy BBCH 34 a 51-59 (tab. 4). Efektem jednokrotnego zastosowania fungicydu $\mathrm{w}$ fazie kwitnienia był także statystycznie istotny wzrost masy tysiąca ziaren o 2\% w stosunku do kontroli (tab. 3). W badaniach prowadzonych w latach 2011-2012 nad wpływem terminu aplikacji środków grzybobójczych, najwyższy wzrost masy tysiąca ziaren stwierdzono po zastosowaniu mieszaniny triazolu ze strobiluryną $\mathrm{w}$ fazie 9. kolanka (BBCH 19) (tab. 4). Wegulo i wsp. (1997) stwierdzali znaczącą poprawę wydajności plonowania kukurydzy po zastosowaniu fungicydów. W badaniach prowadzonych przez Blandino i wsp. (2012) największy wzrost plonu uzyskano po zastosowaniu środków grzybobójczych w fazie rozwojowej kukurydzy od BBCH 35 do 65. Obserwacje te są zbieżne $\mathrm{z}$ wynikami badań Paul i wsp. (2011), którzy stwierdzili istotny wzrost plonu ziarna kukurydzy w odniesieniu do kontroli po aplikacjach wykonanych nalistnym fungicydem pomiędzy fazą $\mathrm{BBCH}$ 51-65. Środki grzybobójcze zastosowane później, w fazie dojrzałości mlecznej pomimo istotnego ograniczenia porażenia liści przez sprawcę żółtej plamistości liści kukurydzy tylko w nieznacznym stopniu przyczyniły się do wzrostu plonu ziarna kukurydzy (Blandino i wsp. 2012) (tab. 3, 4).

\section{Wnioski / Conclusions}

1. Zastosowanie ochrony fungicydowej istotnie ograniczyło porażenie liści kukurydzy przez grzyby patogeniczne oraz przyczyniło się do wzrostu zachowanej powierzchni asymilacyjnej, plonu ziarna, zielonej masy, a także masy tysiąca ziaren.

2. Uzyskane wyniki wskazują, że termin aplikacji determinował efektywność działania zastosowanych środków grzybobójczych. Najlepszą aktywność działania fungicydów w ochronie kukurydzy przed sprawcami chorób przyniosło zastosowanie środków w fazie rozwojowej rośliny uprawnej BBCH 39-59 (faza 9. kolanka do fazy całkowicie widocznej wiechy i w pełni ukształtowanej).

3. Pozytywy wpływ fumgicydów na cechy biometryczne kolb kukurydzy obserwowano jedynie w obiektach, w których aplikowano środki w terminie od fazy BBCH 34 do fazy 51-59.

\section{Literatura / References}

Below F.E., Duncan K.A., Uribelarrea M., Ruyle T.B. 2009. Occurrence and proposed cause of hollow husk in maize. Agronomy Journal 101: 237-242.

Blandino M., Galeazzi M., Savoia W., Reyneri A. 2012. Timing of azoxystrobin + propiconazole application on maize to control northern corn leaf blight and maximize grain yield. Field Crops Research 139: 20-29.

Bowen K.L., Pedersen W.L. 1988. Effects of propiconazole on Exserohilum turcicum in laboratory and field studies. Plant Disease 72: 847-850.

Bradley C.A., Ames K.A. 2010. Effect of foliar fungicides on corn with simulated hail damage. Plant Disease 94: 83-86.

Da Cunha J.P.A.R., da Silva L.L., Boller W., Rodrigues J.F. 2010. Aerial and ground fungicide application to corn for disease control. Revista Ciência Agronômica 41: 366-372.

Lejeune P., Bernier G. 1996. Effect of environment on the early steps of ear initiation in maze (Zea mays L.). Plant Cell Environment 19: $217-224$.

Munkvold G.P., Doerge T., Bradley C. 2008. IPM is still alive for corn leaf diseases: Look before you spray. Proceedings of the 62nd Annual Corn \& Sorghum Research Conference Chicago. [CD-ROM]. American Seed Trade Association, Alexandria, VA.

Munkvold G.P., Gorman D. 2006. Foliar fungicide use in corn. Crop Insights 16 (6): 1-6. Pioneer Hi-Bred, Johnston, IA. 
Munkvold G.P., Martinson C.A., Shriver J.M., Dixon P.M. 2001. Probabilities for profitable fungicide use against gray leaf spot in hybrid maize. Phytopathology 91: 477-484.

Nelson P.E., Desjardins A.E., Plattner R.D. 1993. Fumonisins, mycotoxins produced by Fusarium species: biology, chemistry, and significance. Annual Review of Phytopathology 31: 233-252.

Nelson K.A., Meinhardt C.G. 2011. Foliar boron and pyraclostrobin effects on corn. Agronomy Journal 103: 1352-1358.

Pataky J.K., Eastburn D.M. 1993. Comparing partial resistance to Puccinia sorghi and application of fungicides for controlling common rust on sweet corn. Phytopathology 83: 1046-1051.

Paul P.A., Madden L.V., Bradley C.A., Robertson A.E., Munkvold G.P., Shaner G., Wise K.A., Malvich D.K., Allen T.W., Grybauskas A., Vincelli P., Esker P. 2011. Meta-analysis of yield response of hybrid field corn to foliar fungicides in the U.S. Corn Belt. Phytopathology 101: 1122-1132.

Tekiela A. 2001. Najważniejsze choroby kukurydzy. Kukurydza rośliną przyszłości. Poradnik dla producentów. Agro Serwis: $29-31$.

Tekiela A. 2005. Występowanie i szkodliwość drobnej plamistości liści kukurydzy [Aureobasidium zeae (Narita et Hiratsuka) J.N. Dingley] i żółtej plamistości liści kukurydzy (Trichometasphaeria tarcica Luttr.) na kukurydzy w południowo-wschodniej Polsce. [The occurrence and economic importance of eyespot [Aureobasidium zeae (Narita et Hiratsuka) J.N. Dingley] and leaf spot (Trichometasphaeria tarcica Luttr.) of maize diseases in south-eastern Poland]. Progress in Plant Protection/Postępy w Ochronie Roślin 45 (1): 484-486.

Wegulo S.N., Martinson C.A., Rivera-C.J.M., Nutter F.W.Jr. 1997. Model for economic analysis of fungicide usage in hybridcorn seed production. Plant Disease 81: 415-422.

Wu Y.-X., von Tiedemann A. 2001. Physiological effects of azoxystrobin and epoxiconazole on senescence and the oxidative status of wheat. Pesticide Biochemistry and Physiology 71: 1-10. 